\title{
Türk Uzmanların Rus Eğitim Sistemi Hakkındaki Raporlar1
}

DOI: 10.26466/opus.661295

\section{Cengiz Aslan *}

* Öğr. Gör. Dr., Ankara Üniversitesi, Eğitim Bilimleri Fakültesi, Ankara/Türkiye E-Posta: aslancengiz@yahoo.com

ORCID: 0000-0003-3710-9838

$\ddot{O} z$

Ülkelerin birbirleriyle olan siyasal ilişkileri toplumsal kurumlar etkilemektedir. Cumhuriyet'in kuruluş sürecinde Türkiye ve Rusya arasında imzalanan antlaşmalar iki ülke arasında birçok alanda işbirliğinin yasal zeminini oluşturmuştur. Bu antlaşmalarla birlikte siyasi heyetler başta olmak üzere, Türkiye ve Rusya'dan çeşitli heyetlerin ve uzmanlarm karşıllklı ziyaretleri gerçekleşmiştir. Bu çerçevede Atatürk döneminde Sovyet Rusya eğitim sistemini incelemek üzere Rusya'ya heyetler ve uzmanlar gönderilmiştir. Bu çalışmanın amacl, Atatürk döneminde Sovyet Rusya'ya gönderilen uzmanlarn Rus eğitim sistemi hakkında hazırladıkları raporların incelenmesidir. Araştırma, tarihsel bir araştırmadır. Araştırmanın veri kaynakları$n \iota$ Rusya eğitim sistemi hakkında hazırlanan raporlar oluşturmaktadır. Çalı̧̧a kapsamında yer alan veriler, betimsel analiz yaklaşımına göre incelenmiştir. Atatürk döneminde, Rus eğitimini incelemek için 1926'da, Nafi Atuf (Kansu) ve Rıdvan Nafiz (Edgüer), 1933 ve 1934'te Vildan Aşir (Savaşır) ve Cevdet Kerim (İncedayl) Beylerden oluşan bir heyet, 1936'da Rüşü Uzel'in başkanlığında her öğretim derecesinden 40 kişilik öğretmen heyeti ve 1937'de Tekirdağ milletvekili Rahmi Apak Rusya'ya gönderilmiştir. Türk uzmanlar, Rus eğitim sistemi ile ilgili inceleme ve araştırmaların raporlaştırmışlar ve bu raporların Milli Ĕ̈itim Bakanlığı'na sunmuşlardır.

Anahtar Kelimeler: Atatürk dönemi, eğitim raporları, Türk uzmanlar, Rusya 


\title{
Reports of Turkish Experts About The Russian Education System
}

\begin{abstract}
The political relations of countries affect social institutions. The various treaties signed by Turkey and Russia during the establishment process of Turkey Republic provided the legal basis of cooperation between these two countries in many areas. With these treaties, various delegations and the experts from Turkey and Russia visited one another reciprocatively, particularly the visits from political delegations have been realized. Within this framework, during Ataturk's period, delegations and experts were sent to Russia to examine the education system of Soviet Russia. In this study, it is aimed to examine these expert' reports about the Russian education system. This study is designed as a historical research. The data sources of the research are reports published about the Russian education system. In this research, data were analyzed with descriptive analysis method. In Atatürk's period, various visits conducted to Russia to examine their education system. In 1926 Nafi Atuf (Kansu) and Rıdvan Nafiz (Edgüer); in 1933-1934 a committee with members of Vildan Aşir (Savaşır) and Cevdet Kerim (Incedayl); in 1936 a committee composed of 40 teachers and chaired by Rüştü Uzel ; in 1937 Tekirdă̆ deputy Rahmi Apak visited to Russia.The Turkish experts reported their investigations and researchs on the Russian education system and presented these reports to the Ministry of National Education.
\end{abstract}

Keywords: Atatürk's period, education reports, Turkish experts, Russia. 


\section{Giriş}

Ülkelerin birbirleriyle olan siyasal ilişkileri, başta siyaset olmak üzere birçok toplumsal kurumu etkilemektedir. Bu çerçevede Atatürk dönemi Sovyet Sosyalist Cumhuriyetler Birliği (SSCB) ile Türkiye arasındaki dostluk ilişkilerinin dönemin siyasal koşullarından bağımsız gelişemediği söylenebilir. Sonuçta "iki devrimin emperyalizm karşıtlığının aynı cephede buluşturmasıyla", "kuruluş süreçlerinde dayanışma ve işbirliği içinde olduğu" görülmektedir (Perinçek, 2005, s.24; Tellal, 2000, s.15). İki ülkenin dostluk ilişkilerinin başlaması, aynı zamanda Türkiye Büyük Millet Meclisi'nin de ilk dış politika eylemi olan, Atatürk'ün Lenin'e yazdığı 26 Nisan 1920 tarihli mektubuyla olmuştur. Bu mektuplar, iki ülke arasında güven ve saygınlık, birbirlerinin içişlerine karışmama ve ulusal çıkarlarına saygı gösterme temeline dayalı samimi bir dostluk ve yararlı bir işbirliği kurulmasına olanak sağlamıştır (Perinçek, 2005, s.51; Vandov, 1982, s.5-34).

Atatürk döneminde, Türkiye-SSCB arasında 16 Mart 1921'de Moskova'da, Türkiye ile Azerbaycan, Ermenistan ve Gürcistan Sovyet Cumhuriyetleri arasında 13 Ekim 1921'de Kars'ta, Ukrayna Sosyalist Cumhuriyeti ile Türkiye arasında 2 Ocak 1922'de Ankara'da, 17 Aralık 1925'te Türkiye ile Sovyet Rusya arasında Paris'te dostluk antlaşmaları imzalanmıştır. Yapılan bu antlaşmalar iki ülke arasında birçok alanda işbirliğinin yasal zeminini oluşturmuştur. Atatürk döneminde siyasi heyetler başta olmak üzere, farklı alanlardan heyetler Rusya'ya ziyaretler gerçekleştirmiştir. Özelikle İsmet Paşa'nun 1932'de gerçekleştirdiği Moskova ziyareti “iyi bir aydınlanma, karşılıklı itimadın kuvvetlenmesi ve Sovyet Rusya şartlarının yakından görülmesi" konularında olumlu geçmiştir (İnönü, 2006, s.514). 1930'lu yılların ikinci yarısından itibaren Türk-Rus ilişkileri gerileme aşamasına geçmiştir. Vandov (1982)'a göre Temmuz 1936'da Montrö'deki Boğazlar Konferansı'ndan sonra SSCB ile Türkiye arasındaki ilişkilerde bazı çatlaklar belirmiş, Atatürk'ün ölümünden sonra bunlar derinleşmiştir. Bu süreçte Stalin yönetimindeki SSCB'nin, Boğazları müştereken müdafaa etmeyi teklif etmesi ilişkileri tersine döndürmüştür (Jaeschke, 2011, s.174).

İki ülkenin eğitim ilişkileri, dönemin siyasal-toplumsal-ekonomik koşullarıyla paralellik göstermektedir. 1922'de Lenin döneminin Dışişleri Halk Komiseri Georgiy Vasilyeviç Çiçerin, eğitim halk komiseri A.V. Lunaçarskiy'e yazdığı mektubunda Mustafa Kemal'in ve ülkü arkadaşlarının, Türk 
toplumunun modernleştirilmesi konusundaki çalışmalarını kolaylaştırıcı materyal gönderilmesi için gerekli işlerin yapılması gereği belirtilse (Aralov, 2010, s.126) de özellikle İnönü'nün 1932'deki Rusya ziyaretinden sonra eğitim-kültür ziyaretleri yoğunlaşmıştır.

Bu çalışmada ulaşılan belge ve bilgiler çerçevesinde Atatürk döneminde SSCB'ye gönderilen Türk uzmanların Sovyet eğitim sistemi hakkında hazırladıkları raporlar incelenmiştir. Araştırma tarihsel bir araştırmadır. Araştırmanın veri kaynaklarını Sovyet Rusya eğitim sistemi hakkında hazırlanan raporlar oluşturmaktadır. Çalışma kapsamında yer alan dokümanlar, betimsel analiz yaklaşımına göre incelenmiştir.

\section{SSCB Eğitim Sistemini İncelemek Üzere Gönderilenler}

1926 yılında, Maarif Vekaleti Müsteşarı Nafi Atuf (Kansu), Teftiş Kurulu Başkanı Rıdvan Nafiz (Edgüer), müfettiş-i umumi Salih Zeki ve Hilmi Beyler'den oluşan heyet, Sovyet Rusya ile komşu ülkelerdeki Maarif teşkilatını incelemek üzere görevlendirilmiştir (BCA, 30.18.1.1/18.20.13; Kansu ve Kansu, 2011, s.66).

Halkevlerinden bir heyet, 10.07.1933-20.08.1933 tarihinde spor teşkilatı, müze ve sergi işleri, meslek birlikleri gibi konularda incelemelerde bulunmak üzere Rusya'ya gönderilmiştir. 26 Temmuz-1 Eylül 1934 tarihlerinde tekrar Türkiye'den bir spor heyeti Rusya'ya gitmiştir. Hem 1933'teki hem de 1934'teki Rusya seyahatine Vildan Aşir (Savaşır) ve Cevdet Kerim (İncedayı) Beyler katılmıştır (BCA, 490.1.0.0/1105.36.1).

1936 yilında Sovyetler Birliği Maarif Komiseri Bubnof tarafindan davet edilen, "gidiş-geliş yol masrafları Sovyet Hükümetince karşılanan" (BCA,30.18.1.2/68.73.18), her öğretim derecesinden seçilen 40 kişilik öğretmenler heyeti incelemelerde bulunmak üzere SSCB'ye gitmiştir. 29 Ağustos-20 Eylül 1936 tarihinde ${ }^{1}$, Rüştü Uzel'in başkanlığında, ilkokul, ortaokul, lise ve enstitü öğretmenleri ile üniversiteden dört doçentten ${ }^{2}$ oluşan 40 kişi-

\footnotetext{
${ }^{1}$ Velidedeoğlu anılarında 25-28 Eylül tarihlerini verse de yükseköğretim hakkında hazırladığı raporda, 29 Ağustos'ta İstanbul'dan hareket ettiklerini, 20 Eylül'de Istanbul'a döndüklerini belirtmektedir.

2 Tıp Fakültesi'nden Dr. Muzaffer Şevki Yener ve Dr. Nebil Bilhan, Fen Fakültesi'nden Ali Rıza Berkem, Hukuk Fakültesi'nden Hıfzı Veldet Velidedeoğlu.
} 
lik heyette ${ }^{3}$ Adnan Saygun gibi bestecilerin dışında Abidin Daver ve Sadri Ertem gibi çeşitli gazeteci ve yazarlar da bulunmaktadır(Velidedeoğlu, 1977, s.214-245).

1937 yılında Tekirdağ milletvekili Rahmi Apak, Sovyet Rusya Spor ve Beden Terbiyesi Teşkilatını incelemek üzere Rusya'da incelemelerde bulunmuştur.4 (BCA, 490.1.0.0/1105.36.1). Tablo 1'de Atatürk dönemi Rusya eğitim sistemi ile ilgili dönemin çeşitli dergilerinde yayınlanan rapor, yazı ve çeviriler yer almaktadır. Bu çalışmada Tablo 1'de yer alan yazılardan sadece, Sovyet Rusya eğitim sistemi ile ilgili hazırlanan raporlar değerlendirilmiştir. 1926'da Maarif Vekaleti Mecmuasında yayınlanan, Türkiye'nin Rusya Büyükelçisi Zekâi (Apaydın) Beyin hazırladığı rapor ${ }^{5}$ eğitim sistemini incelemek üzere gönderilmediği için çalışma kapsamında ele alınmamıştır. Dolayısıyla bu çalışmada, ulaşılan belge ve bilgiler çerçevesinde, Sovyet Rusya eğitim sistemini incelemek için gönderilen uzmanların hazırladıkları raporlardan 9'u değerlendirilmiştir.

Tablo 1. Sovyet Rusya Ĕ̆itim Sistemi Hakkında Hazırlanan Yazı ve Raporlar (19261937)

\begin{tabular}{|c|c|c|c|c|}
\hline $\mathrm{S}$ & Yil & Başlık & $\begin{array}{l}\text { Yazar / } \\
\text { Hazirlayan }\end{array}$ & Yayın. Yer \\
\hline 1 & 1926 & Rusya Maarifi Hakkında Rapor (rapor) & $\begin{array}{l}\text { Nafi Atuf / } \\
\text { Ridvan Nafiz }\end{array}$ & $\begin{array}{l}\text { Maarif Vekaleti } \\
\text { Mec. (MVM) }\end{array}$ \\
\hline 2 & 1926 & Rusya Maarifi Hakkında (rapor) & $\begin{array}{l}\text { Zekâi } \\
\text { (Apaydın) }\end{array}$ & " \\
\hline 3 & 1926 & Rus Tek İş Mektebi (Tercüme) & $\begin{array}{l}\text { Tolstoy, } \\
\text { Yako Veleva }\end{array}$ & " \\
\hline 4 & 1926 & $\begin{array}{l}\text { Rus Tek İş Mekteplerinin Bina } \\
\text { Ve Vesaiti (Tercüme) }\end{array}$ & & " \\
\hline 5 & 1927 & Rusya'da Bir Tecrübe Mektebi & Ridvan Nafiz & Terbiye \\
\hline 6 & 1927 & Moskova'da Radişcef Tek İş Mektebi & Ridvan Nafiz & " \\
\hline
\end{tabular}

\footnotetext{
${ }^{3}$ Heyette, Orta Tedrisat Müdür muavini Hayri, Erzurum Lisesi müdür muavini Arif, İstanbul Kız Muallim Mektebi, öğretmenlerinden Hüviyet Bekir, Gazi Terbiye Enstitüsü öğretmenlerinden, Mustafa Nihad (Özön), Gaziantep Maarif müdürü Hüseyin Arif, Maarif Vekâleti şube direktörlerinden Halil Vedad (Fıratlı) ve eşi Nahide Vedat da yer almaktadır (Cumhuriyet, 30 Ağustos 1936, s. 2).

44 Temmuz 1937 tarihinde, Içişleri Bakanı ve CHP Genel Sekreteri Şükrü Kaya, Dışişleri Bakanı Tevfik Rüştü Aras ve beraberindeki heyet 20 günlük bir ziyaret için Moskova'ya gider. Rahmi Apak da bu seyahate katılanlardan biridir. Bk. Vandov, 1982, s.123; Rahmi Apak, Yetmişlik bir subayın hatıraları, Türk Tarih Kurumu Yayınları, Ankara, 1988, s.278,279.

${ }^{5}$ Zekai Beyin bu raporunda, Rusya eğitim sisteminin her kademesinin ele alındığı, eğitim bütçeleri ve programlarına ayrıntılarıyla yer verildiği belirtilmektedir. Bk. Gönül Türkan Demir, 1918-1938 yılları arasında yayınlanan eğitim dergilerindeki karşılaştırmalı eğitim makaleleri, Cumhuriyet International Journal of Education, 6(1), 2017, s.28.
} 


\begin{tabular}{|c|c|c|c|c|}
\hline 7 & 1927 & $\begin{array}{l}\text { Yeni Programlardan - } \\
\text { Rus Müfredat Programları }\end{array}$ & $\begin{array}{l}\text { Hıfzırrahman } \\
\text { Raşid(Öymen) }\end{array}$ & $\begin{array}{l}\text { Muallimler } \\
\text { Mecmuası }\end{array}$ \\
\hline 8 & 1927 & $\begin{array}{l}\text { Rusya Şuralar İttihadı Sosyalist } \\
\text { Cumhuriyetinde Maarif-i Umumiye }\end{array}$ & A. Âli & Fikirler \\
\hline 9 & 1927 & $\begin{array}{l}\text { Rusya Şuralar İttihadı Sosyalist } \\
\text { Cumhuriyetinde Maarif-i } \\
\text { Umumiye-Tedrisat-1 Meslekiye }\end{array}$ & A. Âli & " \\
\hline 10 & 1927 & $\begin{array}{l}\text { Rus Şuralar İttihatında Maarif - } \\
\text { Harsiyi Siyaset Faaliyeti - Kulüpler }\end{array}$ & A. Âli & " \\
\hline 11 & 1927 & $\begin{array}{l}\text { Rus Şuralar Cumhuriyetinde } \\
\text { Terbiye Meselesi }\end{array}$ & Lunaçarski & MVM \\
\hline 12 & 1928 & $\begin{array}{l}\text { Rusya Şuralar İttihadı Sosyalist } \\
\text { Cumhuriyetinde Maarif - İlim }\end{array}$ & A. Âli & " \\
\hline 13 & 1928 & $\begin{array}{l}\text { Sovyet Rusya'nın Pedagoji Teknikum- } \\
\text { larında Usulü Tedris Meselesi }\end{array}$ & - & " \\
\hline 14 & 1928 & $\begin{array}{l}\text { Sovyet Rusya'nın Pedagoji Teknikum- } \\
\text { larında Terbiyevi Tecrübeler (Mevzu', } \\
\text { Gaye-i Teşkilat Ve Fiil-i Tatbik) }\end{array}$ & - & " \\
\hline 15 & 1928 & Rusya'da Maarif & Karlenton Vaşpor & Fikirler \\
\hline 16 & 1930 & Rusya'da metruk çocuk yuvaları & Fuat Refik & $\begin{array}{l}\text { Gürbüz } \\
\text { Türk Çocuğu }\end{array}$ \\
\hline 17 & 1931 & Rusya'da Mektepten Evvelki Terbiye & Kâzım Nami (Duru) & Terbiye \\
\hline 18 & 1933 & Sovyetlerde Bayram ve Terbiye & Nusret Kemal & Ülkü \\
\hline 19 & 1933 & $\begin{array}{l}\text { Rusya'da Beden Terbiyesi ve } \\
\text { Spor (rapor) }\end{array}$ & $\begin{array}{l}\text { Vildan Aşir, Cevdet } \\
\text { Kerim İncedayı }\end{array}$ & Yayınlanmadı \\
\hline 20 & 1934 & Sovyet Rusya'da Spor (rapor) & $\begin{array}{l}\text { Vildan Aşir, } \\
\text { Cevdet Kerim } \\
\text { İncedayı }\end{array}$ & Yayınlanmadı \\
\hline 21 & 1934 & Gençliğin Komünist Birliği (rapor) & $\begin{array}{l}\text { Cevdet } \\
\text { Kerim İncedayı }\end{array}$ & Yayınlanmadı \\
\hline 22 & 1937 & $\begin{array}{l}\text { Sovyet Rusya' da İlköğretim ve Eğitim } \\
\text { İşleri (rapor) }\end{array}$ & Heyet & Kültür Bak. \\
\hline 23 & 1937 & $\begin{array}{l}\text { Sovyet Rusya'da Yüksek Tahsil ve } \\
\text { İlim Hayatı Hakkında Rapor (rapor) }\end{array}$ & $\begin{array}{l}\text { Hıfzı Veldet } \\
\text { Velidedeoğlu }\end{array}$ & Yayınlanmadı \\
\hline 24 & 1937 & $\begin{array}{l}\text { Sovyet Rusya Spor ve Beden } \\
\text { Terbiyesi Teşkilatı Hakkında (rapor) }\end{array}$ & Rahmi Apak & Yayınlanmadı \\
\hline
\end{tabular}

\section{Sovyet Rusya Eğitim Sistemi Hakkında Hazırlanan Raporlar}

1926 yılında, Nafi Atuf (Kansu) ve Rıdvan Nafiz (Edgüer) Beylerin Maarif Vekaleti'ne sundukları rapor, "Rusya Maarifi Hakkında Rapor" başlı̆̆ıyla Maarif Vekâleti Mecmuasında yayınlanmıştır. Raporda, eğitim işlerinden sorumlu olan eğitim Halk Komiserliği'nin (Narkompros) örgütlenmesi ve işleyişi ile vilayetlerdeki okulöncesi eğitim, örgün eğitim, meslek okulları, teknikumlar- orta meslek okulları- işçi fakülteleri, işçi kursları, yüksek mes- 
lek okulları, diğer çocuk bakım kurumları, öğretmenlerin yetiştirilmesi, pedagoji enstitüleri hakkında bilgiler verilmektedir. Bunun yanı sıra raporda yeni rejimin, yeni prensip ve fikirleri halka indirmek, halkın siyasi ve toplumsal eğitimini sağlamak, yeni devlet şeklini sahiplenecek ve koruyacak bir nesil yetiştirmek için eğitim kurumlarını devletin amaçlarına göre oluşturmayı önemli görevleri arasında kabul ettiği belirtilmektedir (Akt. Kansu ve Kansu, 2011, s.409-450; MVM, 1926, s.1-44; Karagöz, 2019, s.26-37). Bu raporun yanı sira, Rusya seyahati sonucunda Ridvan Nafiz Beyin, 1927 yılında Terbiye dergisinde "Rusya'da Bir Tecrübe Mektebi" ile "Moskova'da Radişcef Tek İş Mektebi" başlıklı iki yazısı yayınlanır. Nafi Atuf Bey ile hazırladıkları raporda da kısaca belirttikleri bu okullarla ilgili ayrıntı bilgileri içeren birer rapor niteliğindeki bu yazılarda, Tecrübe Mektebi'nin kuruluş amaçları ile eğitim-öğretim uygulama ve anlayışları (Terbiye, 1927a, s.17-22), Radişcef Tek İş Mektebi'nin süresi, programda yer alan dersleri ve uygulanması gibi eğitim-öğretim süreçleri anlatılmaktadır (Terbiye, 1927b, s. 122-130).

10.07.1933-20.08.1933 tarihlerinde Vildan Aşir ve Cevdet Kerim Beylerin de yer aldığı Halkevleri Spor Heyeti Rusya'ya gitmiştir. "Rusya'da Beden Terbiyesi ve Spor" başlıklı rapor 40 günlük ziyaret sonucunda hazırlanmıştır. Raporda, seyahatte çekilen fotoğraflar, Rusya'nun sanayideki ilerlemesini gösteren dergiler, albümler, istatistikler ve nizamnamelerle birlikte, Sovyet spor teşkilatı, müze ve sergi işleri, meslek birlikleri gibi konular hakkında ayrıntılı bilgiler bulunmaktadır. Ayrıca raporda, Leningrad, Moskova ve Harkof'ta bulunan beden terbiyesi enstitüleri, ders çizelgeleri, jimnastik mektepleri, stat işleri, Moskova kültür ve istirahat parkları ile çocuk kampları ve beden terbiyesi teşkilatlanmasında her bir oluşumun geniş halk kitlelerine ulaşmadaki yeri ve işleyişi hakkında ayrıntılı bilgiler yer almaktadır. Özellikle şu ya da bu maksatla toplanılacak büyük alanlar olan statların, halkı cezbedecek sıhhi ve nezih eğlenceleri barındıran bir park olduğu, kültür ve istirahat parkları ile birlikte rejimin prensiplerini yansıttığı belirtilmektedir (BCA, 490.1.0.0/1105.36.1).

26 Temmuz-1 Eylül 1934 tarihlerinde futbol, güreş, deniz sporları uzmanlarının da olduğu Halkevleri Spor Heyeti, Sovyet Spor Teşkilatı, müze ve sergi işleri, meslek birlikleri gibi konularda incelemelerde bulunmak üzere Rusya'ya gitmiştir. Heyettekilerden Vildan Aşir (Savaşır) ve Cevdet Kerim (İncedayı) Beyler, "Sovyet Rusya'da Spor" adıyla bu incelemelerini 
raporlaştırmıştır. Diğer bir ifadeyle bu rapor, 1933'teki raporun devamı niteliğinde olup daha fazla bilgiler ve güncel değişiklikleri içermektedir. Raporda, Sovyet spor teşkilatı ayrıntılı olarak anlatılmıştır. Sovyet Rusya'da beden terbiyesi tarihi, beden terbiyesi mektepleri, Moskova ve Leningrad Beden Terbiyesi Enstitüleri, spor bayramları, madalyalar, futbol, güreş, deniz sporları ayrıntılı olarak anlatılmaktadır. Raporda, beden eğitim öğretmenlerinin bisiklet, otomobil, motosiklet kullanmaları, bir motorun özelliklerini bilmeleri, gruplar halinde ülkenin her tarafına dağılarak beden eğitimi faaliyetleri ve gelişimini etüt etmeleri zorunluluğunun, Türkiye'de sadece beden eğitiminde değil aynı zamanda bütün öğretmen okullarında da bulunmasının önemi vurgulanmaktadır. Bunların yanı sıra, sporun ve beden terbiyesinin parti prensibi ve devlet programı kesinliği ve ciddiyetiyle geniş halk kitlelerine maledilmesinin sonucu yüksek başarılar elde edildiği ve Türk takımlarının bu şartlar altında yüz güldürmeyen sonuçlar almasının kaçınılmazlığından söz edilmektedir. Ayrıca raporda Türk futbolunun ilerlemesi ve milli kabiliyetlerin keşfedilmesi için stadyum, idmancıların himayesi, kulüplere olabildiğince yardım, teşkilat çalışanlarının yalnızca bu işle meşgul olmaları ve müfettişlerin görevlendirilmesinin gerekliliği gibi tespitlerde bulunulmaktadır (BCA, 490.1.0.0/1105.36.1).

Cevdet Kerim Bey 1934'teki seyahatinde, Rusya'daki “Gençliğin Komünist Birliği" (Koministiçeski Soyuz Maladiyeci) adlı teşkilat hakkında incelemelerde bulunarak bu konuda da fotoğrafların ve belgelerin olduğu bir rapor hazırlamıştır. Bu rapora göre Konsomol teşkilatı, genç, tecrübeli ve geniş halk kitlelerini Sovyet Rusya'daki Komünist partinin prensiplerine göre idare etmeye alışmış eleman yetiştirmek amacıyla kurulan sıkı disiplinli bir teşkilattır. Partinin bir nevi çırak okulu olan bu teşkilatta gençler iyi birer partici, teknisyen ve memleket müdafasına kabiliyetli ve bilgili olacak biçimde kendisini yetiştirmektedir ve partiye ana üye olarak katılmaktadırlar. Diğer amaçları ise geniş halk ve gençlik kitlelerine sahip kurumlar ve sanayi merkezleri içinde çalışanları, genç komünist vasfinın mecburiyetleri altında sevk, idare ve kontrol, kurumların çalışmalarını, rejime bağllıklarını ve teşkilat dışında kalanları kontrol etmektir. Teşkilatın en küçük biriminden en büyük birimine növe ${ }^{6}$, komiteler, mintıkalar, vilayetler, cumhuriyet-

\footnotetext{
${ }^{6}$ Növe, bir fabrikada, müessesede, devlet dairesinde, okulda toplanan genç komünistlerden oluşan en küçük birimdir. Her növenin kendi arasından seçtiği, organizatör adı verilen bir şefi vardır. Növelerin
} 
ler, birliğin genel merkezi biçiminde sıralanmaktadır. Raporda bu teşkilatın işleyişi, teşkilatlanması, günlük işleri fotoğraflarla ve Rusça belgelerle ayrınt1lı olarak anlatılmaktadır (BCA, 490.1.0.0/1105.36.1).

29 Ağustos-20 Eylül 1936 tarihinde farklı okul türleri ve kademelerinden oluşan Türk öğretmen heyetinin üç hafta süren Rusya incelemelerinin sonucunda Bakanlığa verdikleri raporlardan derlenen 26 sayfalık rapor, "Sovyet Rusya'da İlköğretim ve Eğitim İşleri" başlığıyla 1937 yılında Kültür Bakanlığı Dergisi'nde yayımlanmıştır. Raporda Rusya'daki ilköğretim kademesi ayrıntılı olarak anlatılmaktadır. Okulöncesi eğitim kurumları (çocuk bakımevleri, yeni doğmuş çocuklar koğuşu, çocuk yuvaları), halk eğitiminin teşkilatlanması ve işleyişi, zorunlu eğitim yaşındaki çocukların öğretim ve eğitim kurumları, eğitim yönetimi, okulların ders programları ve işleyişi, ilkokul kitapları, çocuk yayınları, halk neşriyatı, köy okulları teşkilatı, köy öğretmenleri, köyde ümmilikle mücadele ve halk eğitimi, ilköğretimde teftiş işleri, tecrübe okulları ve faaliyetleri, ilkokul öğretmenleri ve öğretmen yetiştirme yolları anlatılmaktadır (Kültür Bakanlığı Dergisi, 1937, s.198-241).

29 Ağustos-20 Eylül 1936 tarihinde Rusya'ya giden heyetteki her bir eğitimci bu incelemelerini ayrı ayrı raporlaştırmıştır. Kültür Bakanlığı (Milli Eğitim) bu seyahate katılan bazı eğitimcilerden Sovyet Rusya'nın eğitim ve kültür hayatı hakkında verilen bu özel raporlardan hareketle eğitim ve kültür hayatının her bir bölümü hakkında ayrı raporlar hazırlamalarını istemiştir (Taşdemirci, 2001, s.1). Örneğin 'Sovyet Rusya'da Yüksek Tahsil ve İlim Hayatı Hakkında Rapor' başlıklı inceleme bu seyahate katılan Velidedeoğlu tarafından hazırlanmıştır. Velidedeoğlu'nun bu konuda hazırladığı 22 sayfalık "Sovyet Rusya'da Yüksek Tahsil ve İlim Hayatı Hakkında Rapor" yedi bölümden oluşmaktadır: Birinci bölümde genel olarak Sovyetlerde yükseköğretim sistemi kısaca tanıtılmıştır. Diğer bölümlerde Üniversiteler, Yüksek Teknik Okulları, Tıp Fakültesi, hastaneler ve dinlenme yerleri, Sosyal Bilimlere ait yüksekokullar, Yüksek Pedagoji Enstitüleri, dil öğretimi ve gençlik teşkilatı ana hatlarıyla anlatılmaktadır. Raporda 1935 yılı itibariyle Rusya'da 23 üniversitede 32.000 öğrencinin öğrenim gördüğü; üniversitelerde Matematik-Mekanik, Fizik, Kimya, Biyoloji, Coğrafya ve İlm-i Arz (jeoloji), Tarih olmak üzere 6 fakülteli bir yapı olduğu; 17-35 yaşlarında kız

birden fazla olması durumunda komiteler oluşur. Konsomol teşkilatının ve partinin tüm işlerini yöneten bu komitelerdir. 
ve erkeklerin yükseköğrenime ücretsiz olarak kabul edildiği; üniversitelere bağlı Bilimsel Araştırma Enstitüleri ve müzelerin yanı sıra, genç işçi ve köylülerin üniversiteye kabul edilebilmeleri için öğrenim süresi 3 yıl ve gecegündüz programları olan "İşçi Fakülteleri"nin bulunduğu belirtilmektedir (Akt. Taşdemirci, 2001, s.2-18).

1937'nin Temmuz ayında Tekirdağ milletvekili Rahmi Apak Rusya seyahati sonucunda, "Sovyet Rusya Spor ve Beden Terbiyesi Teşkilatı Hakkında" bir rapor hazırlamıştır. Bu seyahat raporuna göre Sovyetler Birliğinde spor ve beden terbiyesi ile Bakanlar Kurulu nezdinde, Beden Terbiyesi ve Spor İşleri Tekmil Sovyetler İttihadı Komitesi uğraşmaktadır. Raporda bu komitenin Eğitim ve Sağlık Bakanlığı gibi ayrı olmadığını, tüm Sovyetleri kapsadığı, Başkanı ve iki üyesinin Hükümet tarafından atandığı, 23 federasyondan müfettişler; Mekteplerin, Üniversiteler, Yüksekokullar, Ortaokullar ve Köyler Beden Terbiyesi Daireleri; idare kısmı, proje (mimar), sinema ve hariciye daireleri ile Yüksek Beden Terbiyesi Enstitülerinden oluştuğu, Rusya'nın spor bakımından 32 bölgeye ayrıldığı, bu bölgelere, merkezden, tüm cumhuriyetlerin kendi bütçesinden, eyaletlerin bütçesinden ve her Bakanlığın spor için ayırdığı bütçeden yardım yapıldığı, bu bütçelerin dışında, üye aidatları, sahalardan elde edilen gelirler ve fabrikaların yaptıkları yardımlardan oluşan spor bütçesinin bu komite tarafından düzenlendiği; Dinamo, Lokomotif, Spartak gibi mesleki teşekküllerin kurduğu spor kulüplerinin bulunduğu belirtilmektedir. Ayrıca raporda, yüksekokullar ve kurumlar için yüksek niteliklere sahip öğretmen yetiştirmek amacıyla Moskova, Leningrad, Harkof, Bakü ve Tiflis'te Yüksek Beden Terbiyesi Enstitüsü'nün; spor teşkilatı ve milli cumhuriyetlerin okulları için beden terbiyesi öğretmeni ve antrenör yetiştiren 30 tane öğretmen ve antrenör okulunun; Eğitim Bakanlığı'na bağlı olarak da okullar için beden terbiyesi öğretmeni yetiştiren 28 tane beden terbiyesi okulu bulunduğu belirtilmektedir. Rapordan anlaşıldığına göre, Rahmi Beyden Rusya'daki statlar hakkında da bilgi elde etmesi istenilmiş, ancak sadece Moskova'daki dinamo stadı hakkında bilgi elde edebilmiştir. 100 bin kişilik olan ve 6 milyon Türk lirasına malolan bu statta futbol alanı, koşu pisti, atletizm tesisleri, gazino, restoran, sinema, misafir sporcular için yatakhane, jimnastik, güreş, boks, gülle kaldırma salonları, radyoterapi daireleri, röntgen tesisleri ve çeşitli spor aletlerinin satışı için mağaza bulunmaktadır (BCA, 490.1.0.0/1105.36.1). 


\section{Tartışma ve Sonuç}

Türkiye ve Sovyet Rusya arasındaki Atatürk ve Lenin döneminde başlayan ilişkilerin normalleşmesi sürecinde, iki ülkenin karşılıklı dostluk ziyaretlerini ve ilişkilerini sürdürme ve geliştirme eğiliminde olduğu söylenebilir. Bu eğilimde Cumhuriyet' in temel politikasında şiarı olan "yurtta barış, dünyada barış" ilkesinin ve dünyayla bütünleşme, yenilikleri yakından izleme, kendisi için gerekli ve yararlı olanı alma isteğinin büyük bir etkisi vardır. Kuşkusuz yeni kurulan Cumhuriyet'in modernleşme projesinde eğitim sisteminin etkililiği, çağdaş eğitim düşüncesinden ve deneyiminden yararlanılarak olacaktı. Dolayısıyla, gelişmiş ülkelerdeki eğitim düşüncesi ve uygulamalarından yararlanmanın etkili yollarından biri, eğitim sistemlerini incelemek üzere uzmanların gönderilmesidir. Eğitim alanında 1926'da Nafi Atuf Kansu ve Rıdvan Nafiz Edgüer'in, 1936'da 40 kişilik bir heyetin Sovyet eğitim sistemi ile ilgili incelemeleri üretici eğitim, kimsesiz ve yoksul çocukların eğitimi, öğretmen yetiştirme ve eğitim örgütlerini geliştirme açılarından (Altunya, 2005, s.24), 1933 ve 1934'te Vildan Aşir (Savaşır) ile Cevdet Kerim (İncedayı) ve 1937'de Rahmi Apak'ın incelemeleri ise beden eğitimi ve örgütlenmesi konusunda yararlı olmuştur. Taşdemirci (2001) 'ye göre, 1930'lu yıllarda, Sovyet Rusya'da köy ve şehir için ayrı okul kurma ve ayrı ögretmen yetiştirme uygulamaları bulunmamaktadır. Dolayısıyla Sovyet Rusya'da ilkokullara öğretmen yetiştirmek için kurulan Pedagoji Teknikumları ile Türkiye'de Köy Enstitüleri arasında hiçbir benzerlik bulunmamakta, yine Sovyet Rusya'da orta öğretim kurumlarına öğretmen yetiştirmek için kurulan Pedagoji Enstitüleri ile Türkiye'de Köy Enstitülerine öğretmen yetiştirmek üzere kurulan Yüksek Köy Enstitüsü arasında hiç bir benzerlik bulunmamaktadır. Diğer bir ifadeyle Altunya (2018)'ya göre köye göre öğretmen yetiştirme düşüncesi, II. Meşrutiyet döneminde belirgin biçimde ortaya çıkmış olup 1910'larda İsmail Mahir Efendi tarafindan Meclis'te bir proje olarak dillendirilmiştir.

Rusya'da kurulan yeni rejiminin devamı için 1926'daki raporda belirtilen, eğitim kurumlarının devletin hedeflerine göre oluşturulmasının önemi ile ilgili, Rusya seyahatinde bulunan Falih Rufkı (1931)'nun bu gezisi sonucunda yaptığı değerlendirmesinde olduğu gibi, Türk devrimini organize etme, yeni gençliği yetiştirme ve Türk cemiyetini birkaç hamlede eğitme yöntemlerine ihtiyaç bulunmaktadır. Bu ihtiyaç ve önem, 1936 ilkokul prog- 
ramın amacının "kuvvetli cumhuriyetçi, milliyetçi, halkçı, devletçi, laik, inkılâpçı yurttaşlar yetiştirmek" (Kültür Bakanlığı, 1936, s.6) olarak belirtilmesinde karşılığını bulmuştur. Aslan (2014)'a göre, süreklilik ve ilerleme gibi Cumhuriyet'in modernleşme düşüncesinin yanı sıra, oluşturulmaya çalışılan "yeni insan" tipinin de aşamalı olarak yetiştirme çerçevesinin belirlenmesi ve inşa edilmeye çalışılmasının göstergesidir. Bununla birlikte Türkiye'de yetişkinlerin eğitiminde önemli bir yeri olan ve 1932'de kurulan Halkevleri'nin Rusya'dan esinlendiğini öne sürenler de vardır. Halkevleri talimatnamesine göre, bütün memleketi yeni bir mücadele azmi ile donatmak mecburiyeti bulunmaktadır. Macaristan, Çekoslovakya, İtalya, Almanya ve İngiltere'de bunun için oluşturulmuş kültür teşkilatı bulunmaktadır (CHF, 1932, s.4). Bunun yanı sira Halkevleri talimatnamesinde Rusya'nın telaffuz edilmemesi, her ne kadar Türkiye ve Rusya arasında sıklıkla çeşitli ziyaretler gerçekleştirilse de dönemin siyasi anlayışının sonucu olarak, Türkiye'nin Rusya'ya karşı mesafeli tutumunun sonucu olduğu söylenebilir. Kaldı ki bu tutumu yine de 1949 'da bütçe görüşmelerinde Hamdullah Suphi Tanriöver'in Halkevlerinin Rusya'daki Narodnik hareketiyle ilgili olduğunu söylemesini engellemeyeceği gibi, parti içi muhalefetin Soğuk Savaş ile birlikte, sol düşünceli muhalif kişiler için "Rus yanlısı, komünist" vb. etiketlemelerde bulunmasını da engelleyememiştir. Hamdullah Suphi'ye Cevat Dursunoğlu yanıtta, 1914'ten önce Almanya'da Vetahaus kurumlarının bulunduğunu, Halkevlerinin Türkocakları gibi, Türk ulusunun öz malı olduğunu, kesinlikle dışarıdan gelme bir yanı olmadığını belirtmektedir (Çeçen, 1990, s.35-242).

Günümüzdeki anlamıla halkçllı siyasal bir akım olarak ilk kez 19. yüzyılın ikinci yarısında Rusya'da ortaya çıkmış bir köycülük hareketidir. Narodnik hareketi de denilen bu akım Rusya' da okuyan bazı Türk aydınlarının etkisiyle İttihat ve Terakki içinde de savunulmuştur. Ayrıca, Orta Avrupa ülkelerinde, özellikle Almanya'da Yurttaşevi veya Hemşerievi biçiminde merkezlerle birlikte köylerde Toplumevleri bulunmaktadır. Demokratik ülkelerin demokrasiyi tabana yayma doğrultusunda halk eğitimine ağırlık verme denemelerini Türkiye de yakından takip etmiş özellikle, Selim Sırrı İsveç, Nizamettin Kirşan ve Vildan Aşir'in İsveç ve Kuzey Avrupa ülkeleri ile ilgili incelemeleri geniş bir tartışma ortamı yaratmıştır. Vildan Aşir halk eğitimiyle ilgili, özellikle Çekoslavakya'daki Sokol teşkilatı incelemelerini anlattığı konuşmalarında, Türkiye'de de Sokollar gibi halkevleri- 
nin veya halkınevlerinin kurulabileceğini savunuyordu (Çeçen, 1990, s.35242). Bununla birlikte, Halkevlerinin kuruluş aşamasında oluşturulan komisyonda7, Rusya'da Doğu Emekçileri Komünist Üniversitesi'nde (KUTV/KUTVA) eğitim gören Şevket Süreyya ve İsmail Hüsrev Tökin gibi isimlerin bulunması (Çomak, 2016, s.109), Rusya' daki deneyimden yararlanıldığını düşündürebilir. Oysa, bu isimlerin Kadro Hareketi/Dergisinde, Cumhuriyet devrimlerinin teorik temellerini inşa etme sürecinde, Türk devrimlerinin sözcüsü oldukları (Türkeş, 1999, s.10) ve birikimlerini resmi ideolojiyi desteklemek için kullandıkları görülmektedir (Çomak, 2016, s.109). Dolayısıyla, Halkevlerinin kuruluş sürecinde oluşturulan komisyonlarda farklı ülke deneyimleri olan uzmanların yer almasının sonucu, bu oluşumun Türkiye'ye özgü sentez bir yapı olduğu İsveç, Çekoslavakya, Macaristan, İtalya, Almanya, İngiltere ve Rusya gibi ülkelerin deneyimlerinden yararlanıldığı söylenebilir.

$\mathrm{Bu}$ raporlarda belirtilen diğer bir konu, gençliğin beden terbiyesidir. "Kalplerinde ve dimağlarında memleket sevgisi duyanları", "toplanma ve çalışma yeri" olan Halkevlerinin, Spor şubesi aracılığıyla "Türk gençliğinde ve Türk halkında spor ve beden hareketlerine sevgi ve alaka uyandırmak", "bunları bir kütle hareketi ve milli bir faaliyet haline getirmek" görevi bulunmaktadır (Halkevleri Talimatnamesi,1932, s.12). Bununla birlikte 1922'de kurulan Türkiye İdman Cemiyetleri İttifakı (TiCI), VIII. Kongresi'nde, 1936'da, Türk Spor Kurumu (TSK) adını alarak CHP'ye bağlanmış ve böylelikle siyasal iktidarın kamusal yaşama yönelik müdahaleleri kurumsal düzeyde gerçekleşmiştir. Bu uygulamalar sonucunda, 29 Haziran 1938 tarihli Beden Terbiyesi Kanunu ile gençler için kulüplere girme ve boş zamanlarında beden terbiyesine devam etme zorunluluğu getirilmiştir (Resmi Gazete, 1938, s. 1160). Bu kanunla Türk Spor Kurumu, Başbakanlığa bağlı Beden Terbiyesi Genel Direktörlüğü adını alır. Fişek (1985)'e göre, Genel Müdürlüğün bu statüsüne benzer bir örgütlenme, sadece Bakanlar Kurulunun altında bir devlet komitesi olarak Sovyet Rusya'da bulunduğu için, dönemin Türkiye'sinin dünya spor pratiğine yaptığı ilginç bir katkıdır. Ayrıca bu kanun Aslan (2011)'a göre kalkınma yolunda sağlıklı, disiplinli, üretken,

\footnotetext{
${ }^{7}$ Komisyonda Milli Eğitim Bakanı Dr. Reşit Galip, Şevket Süreyya, Recep Peker, Ali Rana Tarhan, Hasan Cemil Çambel, Ziya Cevher Etili, Münir Hayri Egeli, Cevdet Nasuhi, Ismail Hüsrev Tökin, Isshak Refet, Hamit Zübeyir Koşay, Sadi Irmak, Behçet Kemal Çağlar, Vildan Aşir Savaşır bulunmaktadır. Ayrıntıı bilgi için bk. Anıl Çeçen, Halkevleri, Gündoğan Yayınları, Ankara,1990, s.110.
} 
milli bedenlerin yaratılmasını amaçlayan Cumhuriyet' in öjenist nüfus siyasetinin bir örneği olarak nitelendirilmektedir. 1932'de Birleşik Amerika'nın Türkiye Büyükelçisi Charles H. Sherill Türkiye'de beden terbiyesi ve gençlik örgütü konusunda ne gibi adımlar atıldığını Gazi Mustafa Kemal'e sorduğunda, hiçbir sistemin değişikliğe uğramadan, Türkiye tarafından benimsenemeyeceği yanıtını alır. Bununla birlikte Aslan (2011), Cumhuriyet'in İtalya ve Sovyetler Birliği'ndeki siyasi ideolojilerle arasına mesafe koymasına karşın, bu devletlerin terbiye ve inkişaf metotlarının cazibesinden kendini kurtaramadığı, bunların başında gençlik terbiyesi geldiği değerlendirmesinde bulunsa da dönemin Türk eğitim uygulamalarında, farklı ülke deneyimleri ve kendi koşulları gözetilip karşılaştırmalı biçimde değerlendirilerek bir senteze ulaşıldığı söylenebilir.

Raporlarda belirtilen bir başka konu, halkın beden terbiyesi konusudur. Devlet fabrikalarının bünyelerinde sosyal ve sportif olanakların bulunması ile tüm halkın beden terbiyesi uygulaması Rusya'daki sistemin izlerinin göstergeleri olarak nitelendirilebilse de, aslında savaştan yeni çıkmış bir dünyanın ihtiyaç duyduğu genç ve sağlıklı nesli üretebilmesi ancak bu tür uygulamalarla gerçekleşebilirdi. Dolayısıyla dönemin birçok ülkesinde varolan uygulamalardan haberdar olan Cumhuriyet'in, kendisi için uygun olanı almaması düşünülemeyeceği gibi hangi ülkenin uygulamasını model aldığı sorusunun yanıtı, kuşkusuz takip edilen barışçıl ve bütüncül siyasetle ilgilidir. Birinci Sanayi Planı ile ilgili, 13 Ağustos-8 Ekim 1932 tarihlerinde Türk Hükümeti'nin davetlisi olarak Devlet İnşaat-Proje Tröstü Müdürü Prof. Orlov başkanlığında bir Sovyet uzman heyeti Türkiye'de bulunmuştur. Heyette uzman Glagebin, mimar Nikolaev, Prof. Samgin, jeolog mühendis Troyanski ve planlama uzmanı Kovalevski bulunmaktadır. Sovyet heyeti Ankara, Eskişehir, İzmir, Sarayköy, Kadıköy, Denizli, Konya, Adana, Malatya, Sivas, Kayseri kentlerini ziyaret etmiş, sanayileşme koşul ve olanaklarını araştırmış ve Türkiye'nin hazırlamakta olduğu bu plan için tavsiyelerde bulunmuştur. Bir Türk sanayi heyeti, araştırmalarda bulunmak üzere 1933'ün başlarından Temmuz ortalarına kadar Sovyetler Birliği'nde bulunmuştur. (Vandov, 1982, s.168-170). Akın (2003)'a göre, bu fabrikalarda üretimi arttırmak, hastalıklar dolayısıyla oluşan iş kaybını önlemek ve kronik yorgunluğu azaltmak amacıyla çeşitli spor tesisleri kurulmuştu. Mesela, 1935 senesinde açılan Sümerbank Kayseri tekstil fabrikasında tenis, basket- 
bol ve voleybol kortları, futbol sahası, atış poligonu hatta manej gibi çeşitli spor alanları vardı (Aslan, 2011, s.97).

Raporda belirtilen diğer bir konu ise, Gençliğin Komünist Örgütlenmesi Teşkilatı'nın yapısı ve işleyişidir. Bir gençlik örgütlenmesi olan Konsomol teşkilatı, günümüz siyasal partilerinin gençlik örgütlenmesine, gençlerin parti prensiplerine göre yetişmeleri boyutuyla kısmen benzemektedir. Demirci (2003)'ye göre gençlik örgütlerinin modern devlet tarafından bizzat oluşturulması ya da onların güdümünde, denetiminde, devletin ya da ülkeyi yöneten tek partinin yan örgütlerinden biri olması modem devlet-eğitimgençlik ilişkisinin daha yoğunlaşmış ve az rastlanılan bir yüzü olup en çarpıcı örnekleri Mussollini İtalyası, Stalin Rusyası ve Hitler Almanyası'nda görülmektedir. Bununla birlikte Aydemir (1968)'e göre, Sovyetler'deki gençliği terbiye sistemi ve "ideolojileri bize yabanc ve usulleri bizce benimsenmeye uygun görünmese bile", siyasi ihtilallere sahne olmuş memleketlerde gençliğin, egemen rejimin terbiye nizamı içine alındığı ve ihmal edilmediği belirtilmektedir. Bu dönemde sadece Yugoslavya değil, birçok Avrupa ülkesi gençleri militarize ederek, siyasi iktidarların örgütlü neferleri haline getirmiştir. İtalya'nın Opera Nazionale Balilla'sı, Almanya'nın HitlerJugend'i ve Sovyetler Birliği'nin Komsomol'u bunların başlıcalarıdır (Aslan, 2011, s.86). Halk Partisi'nin aktif isimlerinden Hıfzı Oğuz Bekata'nın çıkardığ 1 Çığır dergisinde tıpkı Rusya'daki Pionnerler, Almanya'daki Kahverengi Gömlekliler ve İtalya'daki Siyah Gömlekliler gibi bir gençlik teşkilatı oluşturulması gerektiği belirtilmiş ve 1935'teki CHP Kurultayında gençlik teşkilatı kurulması kararı alınsa da bu karar Atatürk tarafından durdurulmuştur. (Akşin, 1999, s.103)

Atatürk döneminde Rusya eğitim sistemini incelemek için gönderilen Nafi Atuf, Rıdvan Nafiz, Vildan Âşir, Cevdet Kerim, Hıfzı Veldet ve Rahmi Apak gibi uzmanlar, Milli Eğitim Bakanlı̆̆ı'nın yanı sıra, çeşitli bakanlıklarda taşra ve merkez teşkilatlarında eğitimle ilgili çeşitli görevlerde, kurullarda yer almışlar ve dönemin eğitim politikalarının belirlenmesinde etkin olmuşlardır. Bununla birlikte 1930 yılında, Talim ve Terbiye Heyeti Başkanı Emin (Erişirgil)'in başkanlığında,"yabancı ülkelerde, özellikle Rusya'da olduğu gibi okuma örgütü kurulması ve bir bayilik şirketi oluşturulması, bir okuma seferberliği açılması, köy postalarının düzenlenmesi, posta ücretlerinin indirilmesi ve kitaplarda indirim yapılması" (Bayır, 1971, s.70-72) kararlarının alınması, Rusya hakkında hazırlanan raporlardan yararlanıldığının 
en açık kanıtı olarak kabul edilebilir. Bununla birlikte, 1939 yılında Maarif Vekilliği'nin yayınladığı Türk ve yabancı uzman raporlarının önsözünde belirtildiği gibi tüm raporlardan "yardımcı materyal" olarak yararlanılmıştır. Rusya hakkında hazırlanan raporların, Rusya'nın topyekün bir sistemi nasıl pratize ettiği ve Türkiye'nin bu durumdan kendisi için nasıl faydalanabileceğine dair bilgileri içerdiği söylenebilir. Dolayısıyla Türkiye gibi yeni kurulan ve küllerinden yeniden doğan bir devletin, bütünüyle toplumsal kurumlarda gerçekleştirilen devrimlerin, yenilik ve düzenlemelerin yerleşmesinde, geniş halk kitlelerine ulaşmasında tüm bu raporları, tek bir kaynak olarak kullanmayıp dönemin hakim siyaset anlayışıyla doğru orantılı biçimde, çeşitli ülke eğitim sistemleri hakkında hazırlanan raporlardan da yararlanarak karşılaştırmalı kaynak olarak kullandığı söylenebilir. 


\title{
EXTENDED ABSTRACT
}

\section{Reports of Turkish Experts About The Russian Education System}

\author{
Cengiz Aslan
}

Ankara University

Political relations between countries have strong influence on their social institutions. In this framework, Turkish Russian relations in Atatürk's period is closely related with political relations between these countries in that period. Educational relations were also influenced from the political conditions. Friendly relations between Turkey and Russia started with Atatürk's letter to Lenin on 26 April 1920 (Perinçek, 2005, p.51). Closer relationships started with İsmet Pasha's Moscow visit in 1932. This visit is important to observe Soviet Russian more closely and to improve mutual trust (İnönü, 2006, p.514). After this visit, more educational and cultural visits were conducted to Russia. After the second half of 1930s Turkish Russian relations started to decline and get worse in the Cold War period. Certainly, this situation influenced the educational relations.

The various treaties signed by Turkey and Russia, in the establishment process of Turkey Republic, provided the legal basis of cooperation between these two countries in many areas. With these treaties, various delegations and the experts from Turkey and Russia visited one another reciprocatively, particularly the visits from political delegations have been realized. Within this framework, during Ataturk's period, delegations and experts were sent to Russia to examine the education system of Soviet Russia.

In Atatürk's period more close and friendly relationships have been carried out. One of the reasons is the Republic's political slogan as "peace at home, peace in the world". At the beginning of the Republic educational systems in different countries, without looking at their political regime, have been investigated and this shows the responsive aspects of the new Republic toward developments in the world.

In the literature, although there are various research and publications about Turkish Russian political and economic relations, publications about educational relations are very limited. In the present study experts, sending 
to Soviet Russia in Atatürk's period, and their reports on Russian education system have been investigated in accordance with the reached documents. In this framework, the aim of the study is to investigate educational experts' report on Russian education system in Atatürk's period.

This study is designed as a historical research. Historical researches conduct data systematically and analyze them in an attempt to understand the facts and events in a certain period of history (Fraenkel vd., 2012, p.535-537). The data sources of the research are reports published about the Russian education system in Ataturk's period. In this research, data were analyzed with descriptive analysis method. In this research Directorate of State Archives Republican Archives, National Library of Turkey, various university libraries and electronical documents were investigated and the data gathered analyzed with document analyses method.

In Atatürk's period, various visits conducted to Russia to examine their education system. In 1926 Nafi Atuf (Kansu) and Rıdvan Nafız (Edgüer); in 1933 - 1934 a committee with members of Vildan Aşir (Savaşır) and Cevdet Kerim (Inceday1); in 1936 a committee composed of 40 teachers and chaired by Rüştü Uzel ; in 1937 Tekirdağ deputy Rahmi Apak visited to Russia. Turkish experts, who were sent to Russia in the Atatürk's period, reported their investigations and researches on the Russian education system and presented their reports to the Ministry of National Education.

Nafi Atuf (Kansu) and Rıdvan Nafiz (Edgüer)'s report about visit in 1926 and 40 teachers's report about visit in 1936 are mainly about productive education, orphans and poor children's education, teacher training and improvements of educational institutions (Altunya 2005, p.24). In 1934 Vildan Aşir (Savaşır) and Cevdet Kerim's (İncedayı) visit and Rahmi Apak's visit in 1937 have influence upon physical education and its organization in Turkey.

Experts as Nafi Atuf, Rıdvan Nafiz, Vildan Âşir, Cevdet Kerim, Hıfzı Veldet and Rahmi Apak, who have been sent to Russia in Atatürk's period, worked in various educational committees not only in National Ministry of Education but also in different ministries and they actively influenced the educational policies of the Republic in that period.

The reports on Russian educational system were mainly about practices in educational system in Russia and some suggestions to Turkish education system about possible implications and benefits. Thus, as a newly founded state, Turkey get used of expert reports and their observation about diffe- 
rent educational systems. Not only reports about Russian education system but also reports about other educational systems (like France, Germany, Austria, Bulgaria, Sweden etc.) used as an important source for establishing societal institutions and to disseminate new regulations to wide population. As underlined by The Ministry of Education (Maarif Vekaleti) in their publication "Turkish and foreign experts' reports" in 1939, those expert reports used as "auxilarity material".

\section{Kaynakça / References}

[Atay], Falih Rufkı (1931). Yeni Rusya. Ankara: Hakimiyeti Milliye.

[Edgüer], Rıdvan Nafiz. (1927a). Rusya'da bir Tecrübe Mektebi. Terbiye,1(1), 17-22. [Edgüer], Rıdvan Nafiz. (1927b). Moskova'da Radişcef Tek İş mektebi. Terbiye, 1(2), 122-130.

[Kansu], Nafi Atuf ve [Edgüer], Rıdvan Nafiz. (1926). Rusya maarifi hakkında rapor. Maarif Vekaleti Mecmuası, 2(9), 1-44.

Akşin, S. (1999). Falih Rıfkı Atay'ın Atatürk dönemi gezi kitaplarında ulusçu öğeler. Tarih ve Milliyetçilik, I. Ulusal Tarih Kongresi, 30 Nisan-2 Mayıs 1997, Mersin,Türkiye. Mersin: Mersin Üniversitesi Fen-Edebiyat Fakültesi.

Altunya, N. (2005). Köy enstitüsü sistemine toplu bir bakış. Ankara:Kelebek Matbaası. Altunya, N. (2018). Türkiye'de öğretmen yetiştirme deneyimi. Ankara: Öğretmen Dünyası Yayınları.

Apak, R. (1988).Yetmişlik bir subayın hatıraları. Ankara: Türk Tarih Kurumu Yayınları. Aralov, S, İ. (2010). Bir Sovyet diplomatınin Türkiye anılarn (1922-1923). İstanbul: İş Bankası Yayınları.

Aslan, C. (2014). Erken Cumhuriyet dönemi'nde eğitim bilimleri alanında yurt dışına öğrenci gönderilmesi olgusu (1923-1940). Yayımlanmamış doktora tezi. Ankara Üniversitesi, Ankara.

Aslan, D. A. (2011). Cumhuriyet'in törensel meşruiyeti: Ulus-devlet inşa sürecinde milli bayramlar (1923-1938). Yayımlanmamış doktora tezi. Ankara Üniversitesi, Ankara.

Aydemir, Ş. S. (1968). İnkllâp ve kadro. Ankara: Bilgi Yayınevi.

Bayır, F. O. (1971). Köyün gücü. Ankara: Ulusal Basımevi.

Beden Terbiyesi Kanunu. (1938, 16 Temmuz). Resmi Gazete, (Sayı:3961).

CHF. (1932). Halkevleri talimatnamesi. Ankara: Hakimiyeti Milliye Matbaası.

Çeçen, A. (1990). Halkevleri. Ankara: Gündoğan Yayınları. 
Çomak, İ. (2016). Doğu Emekçileri Komünist Üniversitesi ve burada okuyan Türk öğrenciler hakkında bir rapor. Bilig, 76, 87-115.

Demir, G. T. (2017). 1918-1938 yılları arasında yayınlanan eğitim dergilerindeki karşılaştırmalı eğitim makaleleri. Cumhuriyet International Journal of Education, 6(1), 15-33.

Demirci, H. A. (2003). Tek parti döneminde siyaset - gençlik ilişkilerine bir örnek: Gençlik teşkilatı tasarıları. Ankara Üniversitesi Siyasal Bilgiler Fakültesi Dergisi, 58(2), 55-77.

Devlet Arşivleri Başkanlığ1 (1926, 23 Mart). Sovyet Rusya ile diğer ülkelerdeki Maarif teşkilatını tetkik edecek olan Teftiş Kurulu Başkanı Rıdvan Nafiz, müfettiş Salih Zeki ve Hilmi Beylere siyasi pasaport verilmesi. Cumhuriyet Arşivi (BCA, Fon kodu. 30.18.1.1, Yer no. 18.20.13), Ankara.

Devlet Arşivleri Başkanlığı (1926, 9 Mayıs). Inceleme için Rusya'ya gidecek Maarif Vekaleti Müsteşarı Nafi Atuf Beye siyasi pasaport verilmesi. Cumhuriyet Arşivi (BCA, Fon kodu. 30.18.1.1, Yer no. 18.28.13), Ankara.

Devlet Arşivleri Başkanlığı (1936, 3 Eylül). Ilmi tetkikler için Sovyetler Birliği'ne gidecek heyete 2000 liralık döviz verilmesi. Cumhuriyet Arşivi (BCA, Fon kodu. 30.18.1.2, Yer no. 68.73.18), Ankara.

Devlet Arşivleri Başkanlığı (1937, 10 Ağustos). Türk spor heyetinin Sovyet Rusya seyahati ve Rus spor teşkilatı hakkında raporları. Cumhuriyet Arşivi (BCA, Fon kodu. 490.1.0.0, Yer no. 1105. 36.1), Ankara.

Fişek, K. (1985). 100 soruda Türkiye spor tarihi. İstanbul: Gerçek Yayınevi.

Fraenkel, J. R.,Wallen, N. E. ve Hyun, H. H. (2012). How to design and evaluate research in education. London: McGraw-Hill Higher Education.

İnönü, İ. (2006). Hatıralar (Haz. S. Selek). Ankara: Bilgi Yayınevi.

Jaeschke, G. (2011). 1919 - 1939 yılları arasındaki Türk - Rus yakınlaşması hakkında bir inceleme:Atatürk dönemi Sovyet politikası hakkında, (Çev. H. Zamantil1). Istanbul Journal of Sociological Studies, 19, 159-174.

Kansu, M. A. ve Kansu, K. I. (2011). Cumhuriyet eğitim devriminin mülkiyeli mimarı Nafi Atuf Kansu (1890-1949) yaşamı ve yazıları. Ankara: Mülkiyeliler Birliği Yayınları.

Karagöz, S. (2019). Cumhuriyet dönemi eğitimine yön veren yerli ve yabancı uzman raporları (1911-1927). Ankara: Pegem Akademi Yayıncılı.

Kültür Bakanlığı. (1936). İlkokul programı. İstanbul: Devlet Basımevi.

Kültür Bakanlığı. (1937). Sovyet Rusya'da ilköğretim ve eğitim işleri. Kültür Bakanlığı Dergisi, 20(1), 198-241. 
Perinçek, M. (2005).Atatürk'ün Sovyetler'le görü̈smeleri:Sovyet arşiv belgeleriyle. İstanbul: Kaynak Yayınları.

Rusya'ya giden muallimler (1936, 30 Ağustos). Cumhuriyet, s. 2.

Taşdemirci, E. (2001). 1936 yılında Sovyet Rusya'da yüksek öğretim hakkında hazırlanmış bir rapor ve bu raporun Türkiye'de öğretmen yetiştirme tarihi bakımından önemi. Erciyes Üniversitesi Sosyal Bilimler Enstitüsü Dergisi, 11, 1-37.

Tellal, E. (2000). Uluslararası ve bölgesel gelişmeler çerçevesinde SSCB-Türkiye ilişkileri (1953-1964). Ankara: Mülkiyeliler Birliği Vakfı Yayınları.

Türkeş, M. (1999). Kadro hareketi ulusçu bir sol akım. Ankara: İmge Kitabevi.

Vandov, D. (1982). Atatürk döneminde Sovyet/Türk ilişkileri. Almanya: Fa. Armağan Konrat-Infograph.

Velidedeoğlu, H. V. (1977). Anılarm izinde. İstanbul: Remzi Kitabevi.

\section{Kaynakça Bilgisi / Citation Information}

Aslan, C. (2020). Türk uzmanların Rus eğitim sistemi hakkındaki raporları. OPUS-Uluslararası Toplum Araştırmaları Dergisi, 15(26), 46024622. DOI: 10.26466/opus.661295 